\title{
Histology of bronchial carcinoma in relation to prognosis ${ }^{1}$
}

\author{
A. BRIAN TAYLOR, N.K. SHINTON, AND J.A. H. WATERHOUSE \\ From the United Birmingham Hospitals
}

The treatment of bronchial carcinoma by resection, when it is possible, has become the method of choice. A success rate of about $30 \%$, as five-year survival, is generally agreed, and the Birmingham figures were recently reported by one of us (Taylor, 1960 ), giving $28.9 \%$ alive at five years and $21.4 \%$ alive at 10 years. These figures were from all types of bronchial carcinoma. It has been suggested that the histological character of the growth may considerably affect the results of treatment, even making an operation not worth while for some types.

To investigate this point we have analysed the 2,847 cases diagnosed at the United Birmingham Hospitals from 1948 to 1956 inclusive. In 973 cases histological identification of the type of growth was obtained by bronchoscopy, operation, or necropsy.

\section{SUMMARY OF CASES}

2,847

cases of bronchial carcinoma diagnosed

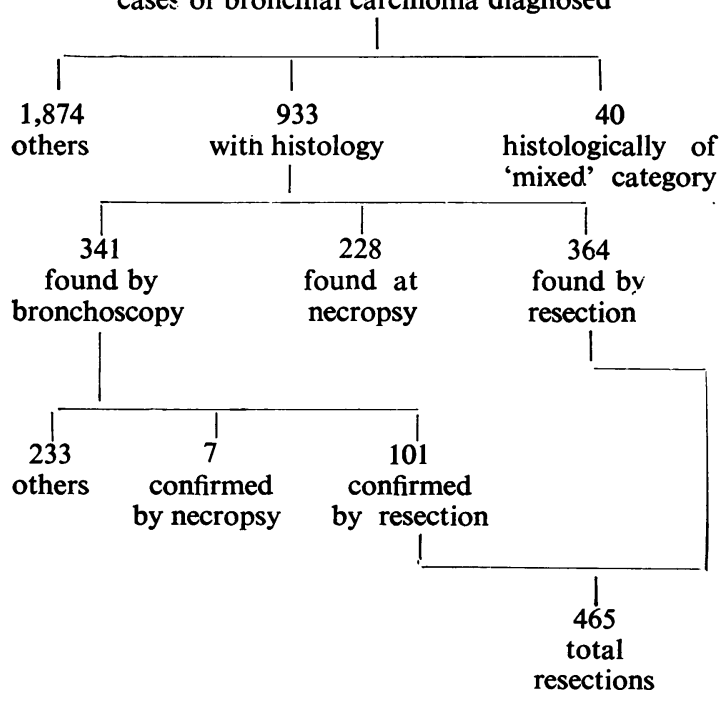

1 Based on a paper given to The Thoracic Society in Paris in July
1962
Of these, 40 were placed in a category classified as 'mixed', adenocystic carcinoma (cylindroma) or carcinoid (malignant adenoma) and therefore excluded, leaving a total of 933 . The primary source of these histological specimens is shown in Table $I$.

T A B L E I

PRIMARY SOURCE OF HISTOLOGICAL SPECIMENS

\begin{tabular}{cc} 
Source & No. of Patients \\
\hline Bronchoscopy & $341(37 \%)$ \\
Resection & $364(39 \%)$ \\
Necropsy & $228(24 \%)$ \\
Total & $933(100 \%)$
\end{tabular}

Of the 341 found by bronchoscopy, 101 were resected and seven came to necropsy. In all, 465 were resected. (Actually in the total 2,847 cases there were 586 resections as some operations were done in hospitals of the Region. The overall resection rate is therefore $21 \%$.) It has been possible to compare the histology found in 108 cases by bronchoscopy with that subsequently found in 101 of them by resection and in 7 of them at necropsy to assess the reliability of bronchoscopic diagnosis.

\section{HISTOLOGY}

The histological identification of bronchial carcinoma is open not only to differences of personal interpretation but also to differences of classification. All our cases have therefore been personally reviewed by one of us (N. K. S.) and we have adopted the classification described in detail by Shinton (1961). Briefly, this divides bronchogenic carcinoma into four main types: adenocarcinoma, squamous carcinoma, oat-cell carcinoma, and undifferentiated (anaplastic) carcinoma.

ADENOCARCINOMA This has cubical or columnar cells arranged as acini and showing mucin secretion.

The group includes 'acinar and trabecular polyhedral cell', 'solid alveolar', 'mucoid', and 'mucus' carcinomas. 
SQUAMOUS-CELL (EPIDERMOID) CARCINOMA This has stratified squamous cells usually with keratinization but sometimes cell-nest formation ('pearls').

The group includes 'transitional cell' and 'round cell and squamous' carcinomas.

OAT (OR SMALL)-CELL CARCINOMA This has small round, oval or spindle-shaped cells with hyperchromatic nuclei and scanty ill-defined cytoplasm arranged in masses, anastomosing ribbons or rosettes.

UNDIFFERENTIATED (ANAPLASTIC) CARCINOMA This has no specific structural or cellular characteristics.

The group includes 'medullary', 'large', 'pleomorphic', 'polygonal', 'polyhedral', 'spheroidal', and 'clear' cell carcinomas.

It was our policy to classify these tumours according to the most differentiated tissue seen. Where more than one type of differentiation was present they were placed into a 'mixed' category. Forty tumours were classified as 'mixed', adenocystic carcinoma (cylindroma) or carcinoid (malignant adenoma), and excluded from the present series. The distribution of histological types in the total number studied and in those found at bronchoscopy is shown in Table II and conforms to most published series except that the number of adenocarcinomas is smaller.

T A B L E I I

COMPARISON OF HISTOLOGICAL TYPES

\begin{tabular}{|c|c|c|c|c|}
\hline \multirow[t]{2}{*}{ Histology } & \multicolumn{2}{|c|}{ All Patients } & \multicolumn{2}{|c|}{$\begin{array}{l}\text { Bronchoscopy } \\
\text { Patients }\end{array}$} \\
\hline & $\%$ & No. & $\%$ & No. \\
\hline $\begin{array}{l}\text { Adenocarcinoma } \\
\text { Squamous carcinoma } \\
\text { Oat-cell carcinoma } \\
\text { Undifferentiated } \\
\text { (anaplastic) carcinoma }\end{array}$ & $\begin{array}{r}5 \cdot 0 \\
56.9 \\
31 \cdot 2 \\
6.9\end{array}$ & $\begin{array}{r}47 \\
531 \\
291 \\
64\end{array}$ & $\begin{array}{r}1 \cdot 5 \\
62 \cdot 5 \\
34 \cdot 3 \\
1 \cdot 7\end{array}$ & $\begin{array}{r}5 \\
213 \\
117 \\
6\end{array}$ \\
\hline Total & 100 & 933 & 100 & 341 \\
\hline
\end{tabular}

\section{RELIABILITY OF BRONCHOSCOPIC DIAGNOSIS}

In assessing the different treatments in relation to the histology of the growth a pre-treatment diagnosis must be available and accurate. Of the 341 cases in this series diagnosed histologically from bronchoscopy, 101 came to resection and seven others came to necropsy. In each case a comparison of the histology was made.

The sections were examined 'blind' without knowledge of their relationship. There was agreement between the histological reports of the bronchoscopic biopsies and the operation or necropsy specimens in 98 of the 108 cases. All the differences were from specimens obtained by biopsy showing squamous cell carcinoma and subsequently from operation or necropsy showing anaplastic carcinoma. The latter were then up-graded into the higher differentiated, i.e., squamous cell, group for further analysis, according to the policy already stated.

Bronchoscopy therefore in this series is reliable in $90 \%$ of cases and the tissue most accessible to biopsy seems to be the most differentiated part of the tumour. Whitwell (1961), analysing 344 cases, found no disagreement in those with adenocarcinoma, $1.7 \%$ difference with squamous carcinoma, $1.5 \%$ difference with oat-cell carcinoma, and $31 \%$ difference with 'carcinoma simplex'. He found higher differentiation in the operation specimen than in the bronchoscopic biopsy specimen and assumed that the main specimen will give the more correct report because so much more tissue is examined histologically. While this may be a reasonable assumption, it seems to us from our results that the bronchial part of the growth may well be more morphologically typical and active than deeper parts in the lung where infection and necrosis have their effect.

Differences in reporting may occur in two ways, either by different histologists recognizing different appearances or by their using different terminologies. In this series these factors had accounted for a difference in $17 \%$ of the original reports before the sections were all rescrutinized by one of us.

\section{RESECTION}

During the years 1948 to 1956 inclusive 586 patients were resected ( 465 at the United Birmingham Hospitals) out of the total of 2,847, giving an average rate of $20.6 \%$. The rate varied during the period between $16.8 \%$ and $25.9 \%$. A bronchoscopic histological diagnosis was made in 341 patients and of these $101(30 \%)$ were resected, the details being shown in Table III. It should be noted that most were squamous or oat-cell growths, the numbers of other types being very small.

Survival after resection can reasonably be assessed at five years. It was shown in our earlier paper (Taylor, 1960) that most deaths after resection

\section{T A B L E I I I}

RESECTION RATE OF 341 PATIENTS WITH BRONCHOSCOPIC DIAGNOSIS

\begin{tabular}{|c|c|c|c|}
\hline \multirow[t]{2}{*}{ Histology } & \multirow[t]{2}{*}{ Total } & \multicolumn{2}{|c|}{ Resection Rate } \\
\hline & & No. & $\%$ \\
\hline $\begin{array}{l}\text { Adenocarcinoma } \\
\text { Squamous carcinoma } \\
\text { Oat-cell carcinoma }\end{array}$ & $\begin{array}{r}5 \\
213 \\
117\end{array}$ & $\begin{array}{r}1 \\
77 \\
23\end{array}$ & $\begin{array}{l}20 \cdot 0 \\
36 \cdot 2 \\
19 \cdot 7\end{array}$ \\
\hline $\begin{array}{l}\text { Undifferentiated (anaplastic) } \\
\text { carcinoma }\end{array}$ & 6 & 0 & 0 \\
\hline Total & 341 & 101 & 30 \\
\hline
\end{tabular}


T A B L E I V

FIVE-YEAR SURVIVAL AFTER RESECTION FOR BRONCHIAL CARCINOMA

\begin{tabular}{|c|c|c|c|c|c|c|}
\hline \multirow[t]{2}{*}{ Histology } & \multicolumn{3}{|c|}{ All Resections } & \multicolumn{3}{|c|}{$\begin{array}{l}\text { Bronchoscopically } \\
\text { Diagnosed }\end{array}$} \\
\hline & $\overline{\text { Total }}$ & Survivors & $s \%$ & Total & Survivors & $s \%$ \\
\hline \multirow{2}{*}{$\begin{array}{l}\text { Adenocarcinoma } \\
\text { Squamous carcinoma } \\
\text { Oat-cell carcinoma } \\
\text { Undifferentiated } \\
\text { (anaplastic) carcinoma }\end{array}$} & $\begin{array}{r}23 \\
328 \\
85\end{array}$ & $\begin{array}{r}3 \\
81 \\
11\end{array}$ & $\begin{array}{l}13.0 \\
24.7 \\
12.9\end{array}$ & $\begin{array}{r}1 \\
77 \\
23\end{array}$ & $\begin{array}{r}0 \\
20 \\
4\end{array}$ & $\begin{array}{r}0 \\
26.0 \\
17.4\end{array}$ \\
\hline & 29 & 2 & 6.9 & \multicolumn{3}{|c|}{ No cases } \\
\hline Total & 465 & 97 & $20 \cdot 9$ & 101 & 24 & $23 \cdot 8$ \\
\hline
\end{tabular}

occurred in the first three years and only a few of the five-year survivors failed to survive 10 years. All the patients have been followed up for five years or to their previous death. The comparison of histology with prognosis is shown in Table IV. Of the total of 465 resections the five-year survival is $21 \%$, and those diagnosed by bronchoscopy before resection follow the rates for the whole group quite closely. It should be noted that the actual numbers of adenocarcinomas and undifferentiated (anaplastic) carcinomas are too small for significant consideration.

\section{DISCUSSION}

The relation of histology to prognosis is not easy to assess accurately. After starting with a large number of patients, by the time one has reached the final analysis of five-year survival for effective resection of a particular histological type they have diminished very greatly, and for those with a pre-operative histological diagnosis the final numbers are indeed small. In this series, however, squamous carcinoma of the bronchus was found twice as often as oat-cell carcinoma, could be resected nearly twice as often as oat-cell carcinoma, and after resection the patient had nearly twice the chance of surviving five years. The numbers for the other types of carcinoma were all so small at each analysis as to be insufficient for reasonable assessment.

Comparison with other reported series of fiveyear survivals after resection shows considerable variation and a number of these are summarized in Table V. The most striking differences are in the figures for adenocarcinoma which vary from 0 to $54 \%$. The squamous carcinomas are much more uniform.

We have considered the possibilities of geographic distribution of variation of histological incidence and identification, as emphasized by Siddons (1962) in his own series of resections, and also a difference of case selection and resection rate. There is a very considerable variation of incidence of adenocarcinoma reported in different series (Shinton, 1961)
T A B L E V

REPORTED FIVE-YEAR SURVIVALS AFTER RESECTION FOR BRONCHIAL CARCINOMA

\begin{tabular}{|c|c|c|c|c|c|}
\hline Author & $\begin{array}{l}\text { Adeno- } \\
\text { carcinoma } \\
(\%)\end{array}$ & $\begin{array}{l}\text { Squamous } \\
\text { Car- } \\
\text { cinoma } \\
(\%)\end{array}$ & $\begin{array}{l}\text { Sat- } \\
\text { cell } \\
\text { Car- } \\
\text { cinoma } \\
(\%)\end{array}$ & $\begin{array}{l}\text { Undifferen- } \\
\text { tiated } \\
\text { (Anaplas- } \\
\text { tic) } \\
\text { Carcinoma } \\
(\%)\end{array}$ & $\begin{array}{l}\text { Total } \\
\text { Resec- } \\
\text { tions }\end{array}$ \\
\hline $\begin{array}{l}\text { Bignall and Moon, } \\
1955 \\
\text { Kirklin et al., } 1955 \\
\text { Gibbon et al., } 1957 \\
\text { Gifford and }\end{array}$ & $\begin{array}{r}41 \\
54 \\
1\end{array}$ & $\begin{array}{l}36 \\
20 \\
24\end{array}$ & 9 & $\begin{array}{l}26 \\
25 \\
13\end{array}$ & $\begin{array}{l}453 \\
844 \\
145\end{array}$ \\
\hline $\begin{array}{l}\text { Gittord and } \\
\text { Waddington, } 1957 \\
\text { Paulson, } 1957 \\
\text { Collins, } 1958 \\
\text { Clagett, 1960 } \\
\text { Spjut et al., 1961 }\end{array}$ & $\begin{array}{r}0 \\
22 \\
9 \\
28 \\
18\end{array}$ & $\begin{array}{l}38 \\
17 \\
21 \\
33 \\
24\end{array}$ & $\begin{array}{rr}0 & \\
0 & \\
0 & \\
15 & \\
& 1\end{array}$ & $\begin{array}{r}19 \\
0 \\
4 \\
4 \\
12\end{array}$ & $\begin{array}{l}464 \\
444 \\
333 \\
584 \\
225\end{array}$ \\
\hline $\begin{array}{l}\text { mith, } 1962 \\
\text { iddons, } 1962 \\
\text { resent series }\end{array}$ & $\begin{array}{l}1 \\
41 \\
13\end{array}$ & $\begin{array}{l}13 \\
36 \\
25\end{array}$ & $\overline{\overline{13}}$ & $\begin{array}{r}2 \\
31 \\
7\end{array}$ & $\begin{array}{l}250 \\
465\end{array}$ \\
\hline
\end{tabular}

whereas squamous carcinomas are much more uniform. We have dealt in detail with the difficulties of histological classification. The selection of cases and the resection rates are very similar in all series and do not seem to have any bearing on individual prognosis of the histological type.

What conclusions may therefore be drawn? From our figures squamous carcinoma is diagnosed in life most often and is most amenable to resection and the patient has a better chance of survival than those with other types of bronchial carcinoma. Oatcell carcinoma is more malignant and the results of resection are not so good. It is possible, therefore, that other forms of treatment, and in particular radiotherapy, may prove to be more effective for oat-cell carcinoma and they demand critical trial. The position for adenocarcinoma remains most confused.

Pre-treatment identification of the cell type seems essential and bronchoscopy is the best way of providing this in most patients. Examination of the sputum, pleural fluid or pleural biopsy may show the histology but generally a direct view of the growth provides the most likely source of reliable histological material as well as assessing the situation macroscopically. We have shown that when a biopsy is obtained it does give a reliable indication of the type of growth present as long as there is agreement among pathologists about classification.

\section{SUMMARY}

From 1948 to 1956 there were 2,847 patients with bronchial carcinoma in the United Birmingham Hospitals, of whom $99(3.5 \%)$ survived five years; all but two had had a resection.

The classification of histology was based on four main groups: adenocarcinoma, squamous cell 
carcinoma, oat-cell carcinoma, and undifferentiated (anaplastic) carcinoma. There were 933 patients in these groups, of whom 465 had a resection and 97 $(21 \%)$ survived five years.

The five-year survival after resection of adenocarcinoma was $13 \%$, of squamous carcinoma $25 \%$, of oat-cell carcinoma $13 \%$, and of undifferentiated carcinoma $7 \%$.

Bronchoscopic histology is reliable. The biopsy and subsequent operation or necropsy specimen agreed in $90 \%$ of 108 cases.

Bronchoscopic histology was obtained in 341 patients. Of these, five had adenocarcinoma $(1.5 \%)$ and one was resected but did not survive; 213 had squamous carcinoma $(62 \%)$ and 77 were resected, of whom $20(26 \%)$ survived five years; 117 had oat- cell carcinoma ( $20 \%$ ) and 23 were resected, of whom four $(17 \%)$ survived five years. Six patients had undifferentiated carcinoma $(1.8 \%)$ and none was resected.

\section{REFERENCES}

Bignall, J. R., and Moon, A. J. (1955). Thorax, 10, 183.

Christiansen, K. H., and Smith, D. E. (1962). J. thorac. cardiovasc. Surg., 43, 267.

Clagett, O. T. (1960). Tex. St. J. Med., 56, 838.

Collins, N. P. (1958). Arch. Surg., 77,925.

Gibbon, J. H., Jr., Templeton, J.'Y., and Nealon, T. F. (1957). Ann. Surg., 145, 637.

Gifford, J. H., and Waddington, J. K. B. (1957). Brit. med. J., 1, 723.

Kirklin, J. W., McDonald, J. R., Clagett, O. T., Moersch, H. J., and Gage, R. P. (1955). Surg. Gynec. Obstet., 100, 429.

Gage, R. P. (1955). Surg. Gynec. Obstet.
Paulson, D. L. (1957). Ann. Surg., 146, 997.

Paulson, D. L. (1957). Ann. Surg., 146, 997 .

Siddons, A. M. H. (1962). Thorax, 17, 308.

Spjut, H. J., Roper, C. L., and Butcher, H. R. (1961). Cancer, 14, 1251 .

Taylor, A. B. (1960). Thorax, 15, 3.

Whitwell, F. (1961). Brit. J. Cancer, 15, 429. 